\title{
Cytogenetic analysis of Baryancistrus xanthellus (Siluriformes: Loricariidae: Ancistrini), an ornamental fish endemic to the Xingu River, Brazil
}

\author{
Larissa A. Medeiros ${ }^{1}$, Eduardo G. Ginani², Leandro M. Sousa ${ }^{3}$, Lúcia H. Rapp Py- \\ Daniel $^{4}$ and Eliana Feldberg ${ }^{1}$
}

\begin{abstract}
Baryancistrus xanthellus is a species from the Ancistrini tribe known commonly as "amarelinho" or "golden nugget pleco". It is one of the most popular and valued ornamental fishes due to its color pattern. Also, it is an endemic species from the Xingu River occurring from Volta Grande do Xingu, region where the Belo Monte Hydropower Dam is being built, to São Félix do Xingu. The current study aimed to cytogenetically characterize $B$. xanthellus. Results point to the maintenance of $2 n=52$, which is considered the most common condition for the tribe, and a single nucleolus organizer region (NOR). Mapping of the 18S rDNA confirmed the NOR sites, and the 5S rDNA was mapped in the interstitial position of a single chromosome pair. The $18 \mathrm{~S}$ and $5 \mathrm{~S}$ rDNA located in different pairs constitute an apomorphy in Loricariidae. Large blocks of heterochromatin are present in pairs 1 and 10 and in the regions equivalent to NOR and the 5S rDNA. Data obtained in this study corroborated with the currently accepted phylogenetic hypothesis for the Ancistrini and demonstrate evidence that the genus Baryancistrus occupies a basal position in the tribe.

Baryancistrus xanthellus é uma espécie da tribo Ancistrini conhecida popularmente como "amarelinho" ou "cascudo pepita de ouro". É um dos peixes ornamentais mais populares e valorizados, devido aos padrões de cor. Também é uma espécie endêmica do rio Xingu, ocorrendo a partir da Volta Grande do Xingu, região onde a Usina Hidrelétrica de Belo Monte está sendo construída, até São Félix do Xingu. O presente estudo teve como objetivo caracterizar citogeneticamente B. xanthellus. Os resultados apontam para a manutenção do $2 \mathrm{n}=52$, considerado a condição mais comum para a tribo, e região organizadora de nucléolo (RON) simples. O mapeamento do DNAr 18S confirmou a marcação da RON e o DNAr 5S foi localizado na posição intersticial de apenas um par cromossômico. A localização dos DNAr $18 \mathrm{~S}$ e $5 \mathrm{~S}$ em diferentes pares configura uma apomorfia em Loricariidae. Grandes blocos de heterocromatina estão presentes nos pares 1 e 10 e nas regiões equivalentes à RON e ao DNAr $5 \mathrm{~S}$. Os dados obtidos neste estudo corroboram a hipótese filogenética atualmente mais aceita para Ancistrini e demonstram evidências que o gênero Baryancistrus ocupa uma posição basal na tribo.
\end{abstract}

Keywords: FISH, Habitat endangered, rDNA, Volta Grande do Xingu.

\section{Introduction}

Loricariidae is a widespread family of fish in the Neotropical region, from Costa Rica until Argentina (Reis et al., 2003). Subfamilies classification and propositions of correlations among the genera has been the subject of constant reformulations (Reis et al., 2006). According to Eschmeyer \& Fong (2015) and Lujan et al. (2015), this family holds around 800 valid species in six subfamilies: Delturinae, Hypoptopomatinae, Hypostominae, Lithogeninae, Loricariinae, and Neoplecostominae (Schaefer, 1987; Reis et al., 2003; Armbruster, 2004; Reis et al., 2006).

\footnotetext{
${ }^{1}$ Instituto Nacional de Pesquisas da Amazônia, Programa de Pós-Graduação em Genética, Conservação e Biologia Evolutiva. Av. André Araújo 2936, Petrópolis, 69.067-375 Manaus, AM, Brazil. (LAM) larissaazmedeiros@gmail.com (corresponding author), (EF) feldberg@inpa.gov.br

${ }^{2}$ Instituto Nacional de Pesquisas da Amazônia, Programa de Pós-Graduação em Entomologia. Av. André Araújo 2936, Petrópolis, 69067-375 Manaus, AM, Brazil. edu.ginani@gmail.com

${ }^{3}$ Universidade Federal do Pará, Campus de Altamira, Faculdade de Ciências Biológicas. Av. Coronel José Porfírio, 2515, Bairro São Sebastião, 68372-040 Altamira, PA, Brazil. leandro.m.sousa@gmail.com

${ }_{4}^{4}$ Instituto Nacional de Pesquisas da Amazônia, Coleções de Peixes. Av. André Araújo, 2936, Petrópolis, 69067-375 Manaus, AM, Brazil. lucia.rapp@gmail.com
} 
Ancistrini belongs to the Hypostominae and has around 217 species (Fisch-Muller, 2003) distributed in 24 genera (Armbruster, 2004; Ferraris, 2007). This tribe includes several species that are taxonomically poorly known and are often misidentified (Alves et al., 2003). In addition, the majority of available studies are based only on morphological data (Isbrücker, 1980; Schaefer, 1986, 1987).

Baryancistrus Rapp Py-Daniel, 1989 is allocated into the Ancistrini and has six described species (Rapp Py-Daniel et al., 2011) that are unique due to their exuberance and diversity of coloration and are, therefore, highly demanded in the fishkeeping market. The presence of yellow spots throughout its body and yellow markings on its dorsal and caudal fins characterize this species. Due to the presence of these spots, which vary in size and intensity, this species is commonly known as "amarelinho" or "golden nugget pleco". This species is rheophilic, and its distribution is strongly linked to the rapids of the Xingu River (Rapp Py-Daniel et al., 2011), which is target for several constructions to take advantage of its hydroelectric potential (Junk \& Mello, 1990). Near the middle of its course, the Xingu River receives the Iriri River and posteriorly suffers an accentuated deflection, forming the region known as the Volta Grande do Xingu. According to Zuanon (1999), the most commonly found species in this part of the river are from the Loricariidae family. Also, according to a report developed by several specialists on Belo Monte dam environmental impacts (Painel de Especialistas - Análise Crítica do Estudo de Impacto Ambiental do Aproveitamento Hidrelétrico de Belo Monte, 2009), the situation of the rheophilic fish there is dire.

Thus, all studies involving these species are extremely important not only for acquiring basic knowledge about them but also to design conservation strategies, since their habitats are being seriously impacted. For the Baryancistrus genus, only $B$. aff. niveatus has cytogenetic data published (Souza et al., 2004). Therefore, the present study investigated the conventional and molecular karyotype macrostructure of one more specie of Baryancistrus, B. xanthellus, in order to increase the information on the genetic diversity of Ancistrini on Amazon region.

\section{Material and Methods}

Thirteen specimens of B. xanthellus (Fig. 1) (six males, four females, and three of unidentified sex) were collected in the Xingu River in the rapids of Volta Grande do Xingu, municipality of Altamira, State of Pará $\left(03^{\circ} 36^{\prime} 31,5^{\prime}\right.$ S $51^{\circ}$ $34^{\prime} 57,4^{\prime \prime} \mathrm{W} ; 03^{\circ} 23^{\prime} 28,2^{\prime \prime} \mathrm{S} 51^{\circ} 44^{\prime} 29,3^{\prime \prime} \mathrm{W} ; 03^{\circ} 22^{\prime} 29,7^{\prime}$ ' S $\left.51^{\circ} 42^{\prime} 25,0^{\prime \prime} \mathrm{W} ; 03^{\circ} 35^{\prime} 38,6^{\prime \prime} \mathrm{S} 51^{\circ} 49^{\prime} 36,0^{\prime \prime} \mathrm{W}\right)$. Collection was performed during free dives in the rapids using a collecting permit (ICMBio SISBIO 10609-1/2007) in the name of Eliana Feldberg, and the specimens were deposited in the fish collection of INPA: INPA 43926, 43927, 43928 and 43929. The Parecer Consubstanciado Sobre Protocolos de Pesquisas no Uso de Animais, number 030/2013, was obtained for the experiments with the specimens.

Mitotic induction was performed with the application of a yeast solution according to the protocol of Oliveira et al. (1988). Mitotic chromosomes were obtained from kidney cells through the air drying technique modified for fishes by Bertollo et al. (1978). For the characterization of the nucleolus organizer regions (NORs), an $\mathrm{AgNO}_{3}$ stain was done according to Howell \& Black (1980). The heterochromatic regions were identified according to the protocol of Sumner (1972).

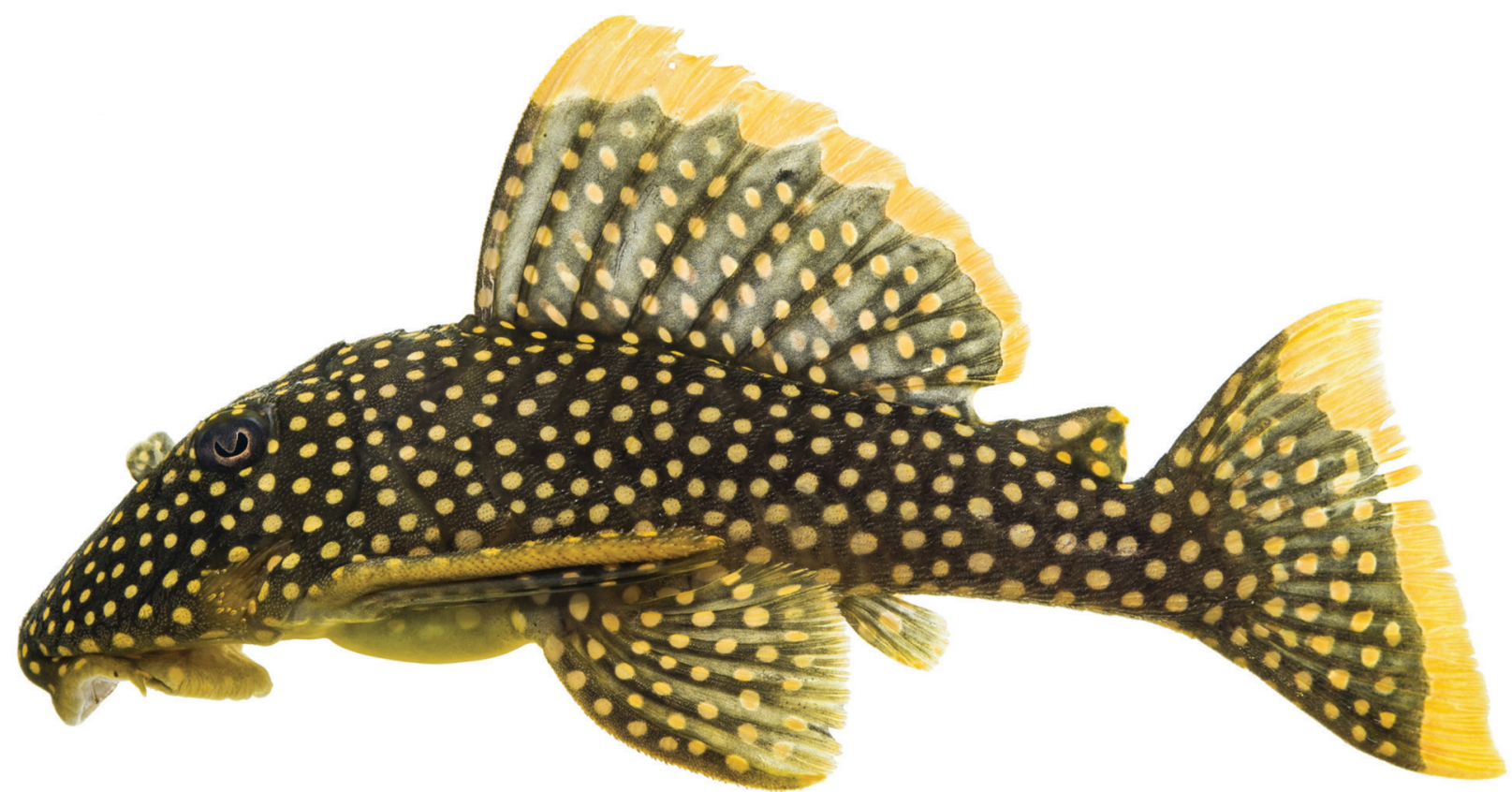

Fig. 1. Live photograph of Baryancistrus xanthellus, LIA 1629. 
DNA extraction followed Sambrook et al. (1989). An amplification through PCR (polymerase chain reaction) was done for the development of $18 \mathrm{~S}$ and 5S rDNA probes using the primers $18 \mathrm{Sf}$ (5'-CCG CTT TGG TGA CTC TTG AT-3') and 18Sr (5'-CCG AGG ACC TCA CTA AAC CA-3') (Gross et al., 2010) and primers 5Sa (5' TAC GCC CGA TCT CGT CCG ATC-3') and 5Sb (5'-CAGGCT GGT ATG GCC GTA AGC-3') (Martins \& Galetti, 1999), respectively. The final volume of each reaction was of $25 \mu$ l containing $200 \mathrm{ng}$ of genomic DNA, $10 \mathrm{X}$ buffer with $1.6 \mathrm{mM}$ of $\mathrm{MgCl}_{2}$, Taq DNA polimerase $(5 \mathrm{U} / \mu \mathrm{l})$, dNTPs $(1 \mathrm{mM})$, primer pair $(5 \mathrm{mM})$ and Milli-Q water. The $18 \mathrm{~S}$ rDNA probe obtained was isolated and labeled with digoxigenin-11-dUTP (Roche Applied Science) through the Nick Translation method and the signal detection was performed using anti-digoxigenin-rhodamine (Roche Applied Science). The 5S rDNA probe was labeled with biotin-16-dUTP (Roche Applied Science) using Nick translation and signal detection was performed using a conjugated avidin-fluorescein (FITC).

The mapping of $18 \mathrm{~S}$ and $5 \mathrm{~S}$ rDNA was obtained through fluorescence in situ hybridization (FISH), following Pinkel et al. (1986) with 77\% strigency (2.5ng/ $\mu 1$ of probes, formamide $50 \%$, dextran sulphate $10 \%$ and $2 \mathrm{xSSC}$ [saline sodium citrate solution] at $37^{\circ} \mathrm{C}$ for $18 \mathrm{~h}$ ). Chromosomes were contrasted with DAPI $(2 \mathrm{mg} / \mathrm{mL})$ in a Vectashield mounting medium (Vector).

The chromosomes were analyzed in an epifluorescence Olympus BX51 microscope and the images were captured with a mounted Olympus DP71 camera through the ImagePro MC 6.3 software. The karyotypes were organized with the aid of the Adobe Photoshop CS6 software, measured with the ImageJ software and classified according to Levan et al. (1964).

\section{Results}

Baryancistrus xanthellus presents a diploid number of 52 chromosomes, $(16 \mathrm{~m}+28 \mathrm{sm}+8 \mathrm{st})$, the fundamental number (FN) was equal 104 for males and females, and no differentiated sexual chromosomes were observed (Fig. 2). Active NOR sites were located at the interstitial portion of the short arm of the fourth metacentric pair of all the individuals analyzed. Size heteromorphism of the NOR was observed between the homologues in some specimens (Fig. 2).

Constitutive heterochromatin was found in the centromeric region in the majority of the chromosomes, extending into the proximal region of both arms in some cases. Large blocks occupied the short arms completely on pair 1 and the long arms of pair 10. The NOR was C-band positive (Fig. 3a).

Mapping of the 18S rDNA confirmed the results obtained by silver staining. As in the Ag-NOR, size heteromorphism was also observed. The 5S rDNA pattern was in the pericentromeric region of metacentric pair 7, which presented a conspicuous heterochromatic block on all analyzed specimens (Fig. 3b).

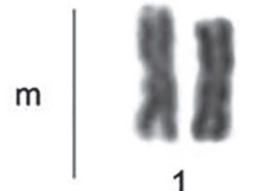

1

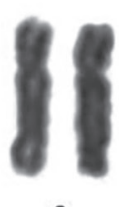

9

sm

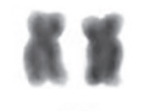

17

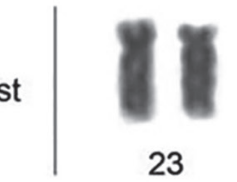

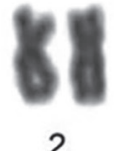

2

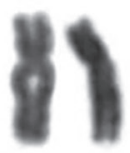

10

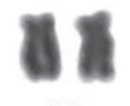

18

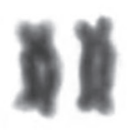

24
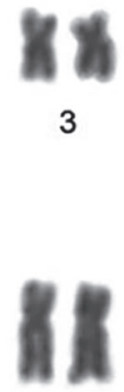

11

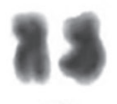

19

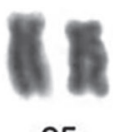

25

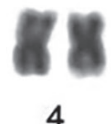

4

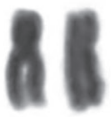

12

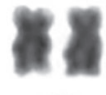

20

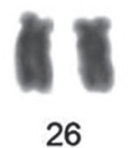

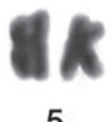

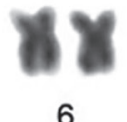

6

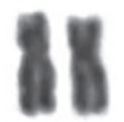

13

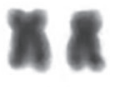

21

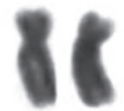

14

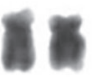

22
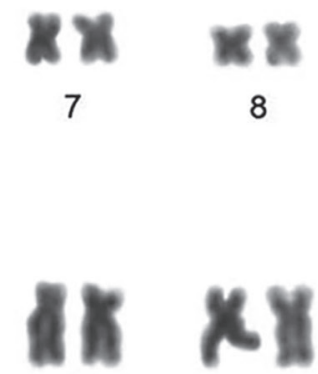

15

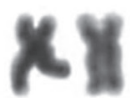

16

Fig. 2. Karyotype of Baryancistrus xanthellus in conventional staining. The square indicates the pair that bears the nucleolus organizer region (NOR). 
a)

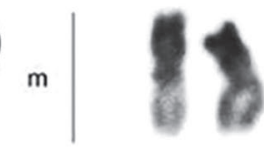

1

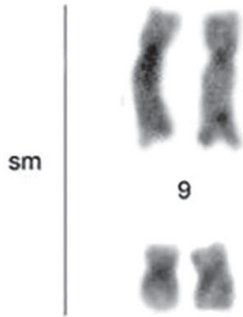

17

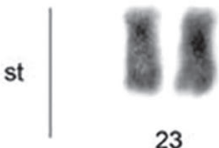

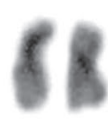

2

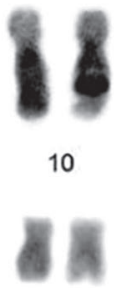

18

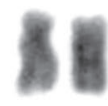

24

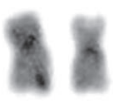

3

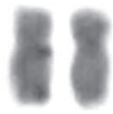

11

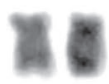

19

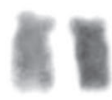

25

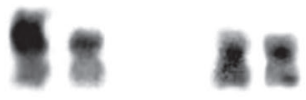

4

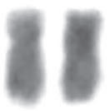

12

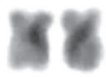

20

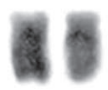

26
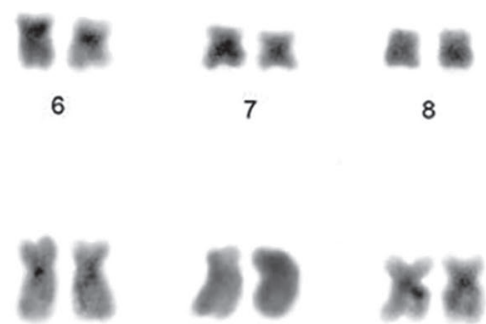

14

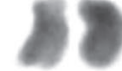

15

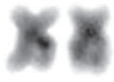

16

$10.0 \mu \mathrm{m}$

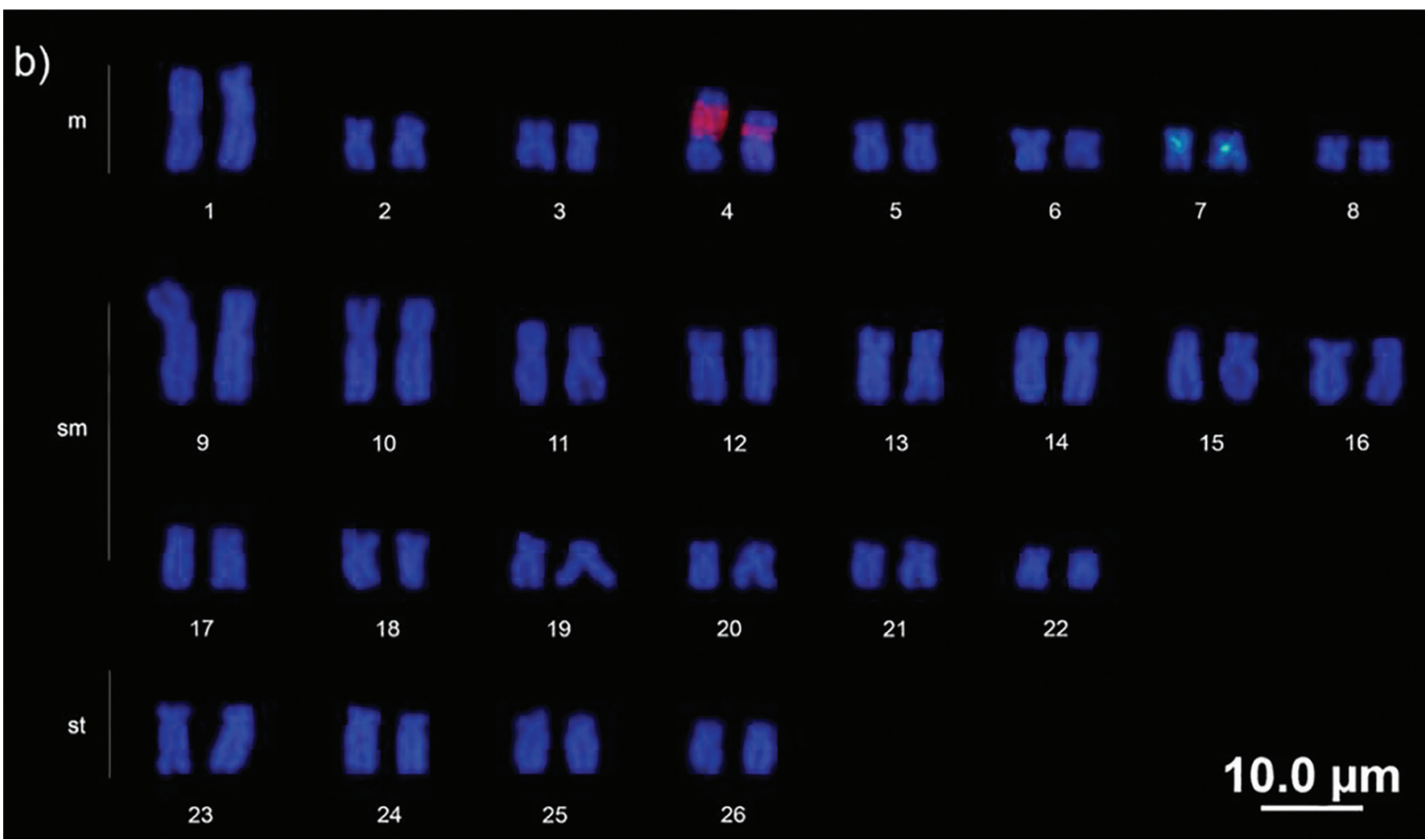

Fig. 3. Karyotype of Baryancistrus xanthellus: a) C-banding; b) Mapping of rDNA 18S (red signal) and 5S (green signal) through double FISH.

\section{Discussion}

Loricariidae, although with only $10 \%$ of species with any cytogenetic published data (Kavalco et al., 2005), present a great karyotypic diversity in relation to the diploid number, ranging from 34 (Hypostominae) to 96 (Delturinae) (Kavalco et al., 2004; Oliveira et al., 2009). The diploid number of 54 chromosomes represents a plesiomorphic condition for this group of fish (Artoni \& Bertollo, 2001; Alves et al., 2005; Kavalco et al., 2005). To the Ancistrini, the diploid number recorded so far is $\leq 54$, indicating the presence of chromosomal rearrangements in the karyoevolution of this taxon (Oliveira et al., 2009; Mariotto et al., 2011). In this tribe, the most frequent diploid number is 52 chromosomes (Table 1). 


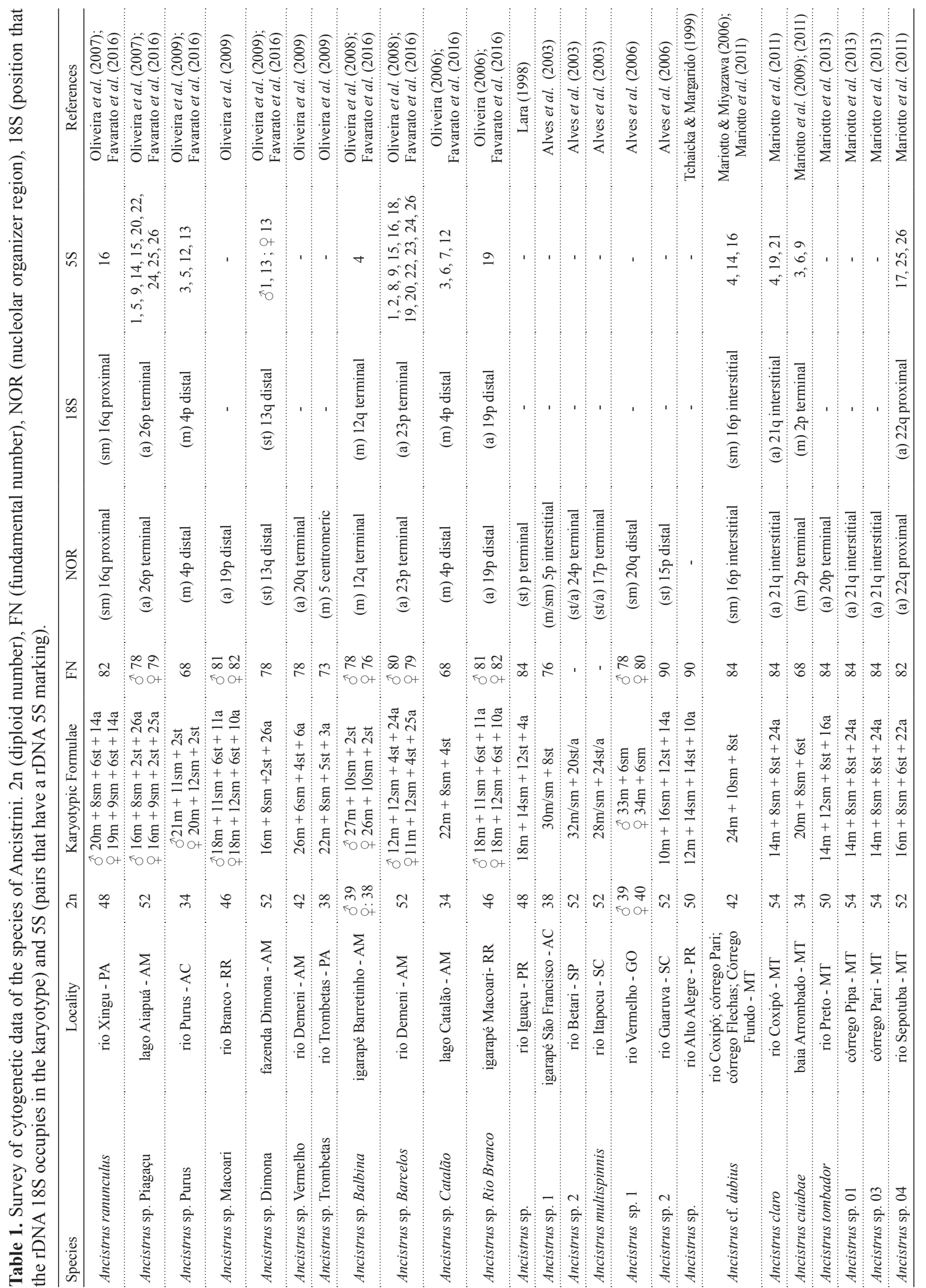




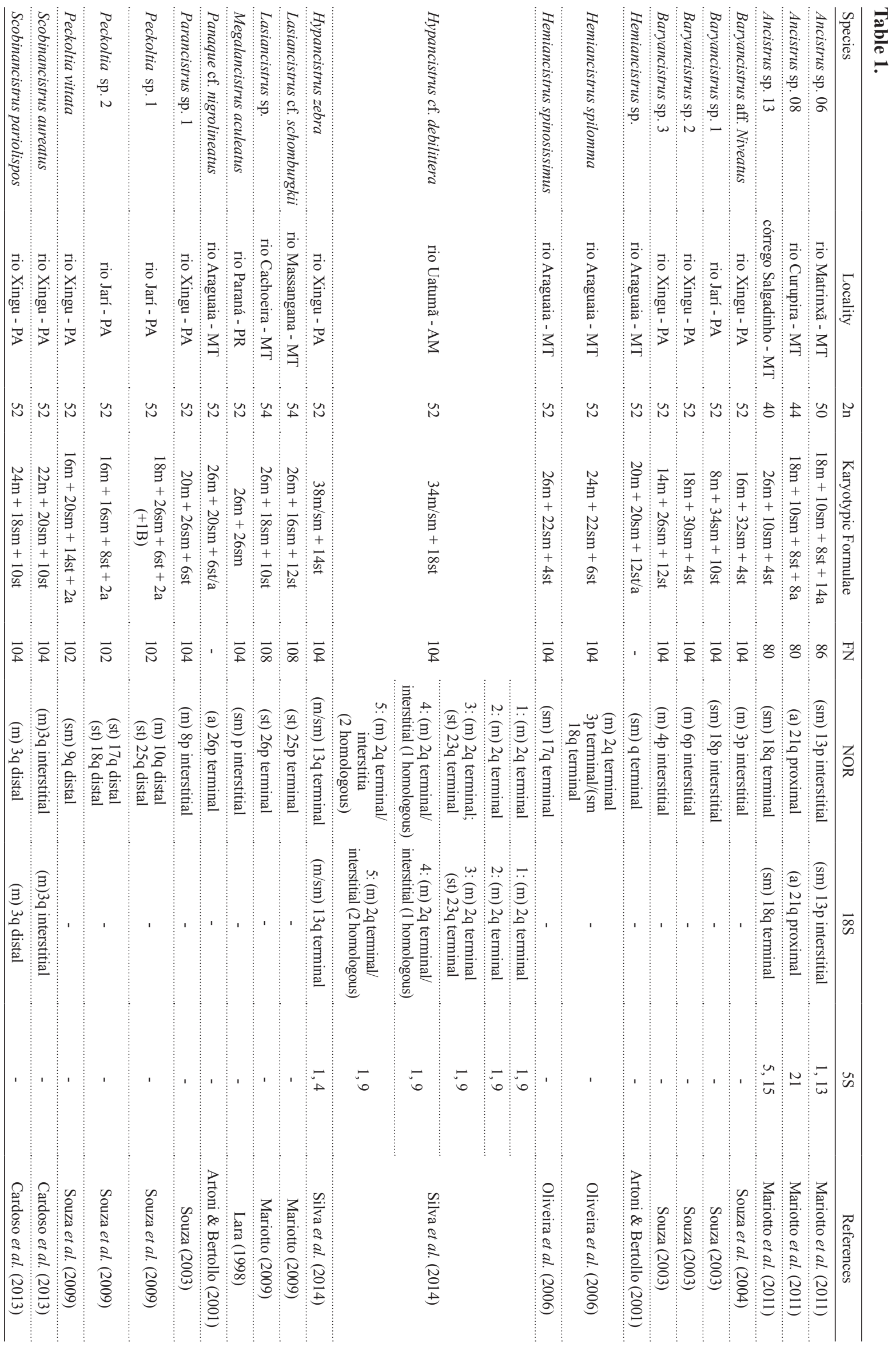


With the exception of Ancistrus, for which the karyotypic differentiation is usually associated to a reduction in the diploid number (Oliveira et al., 2007, 2008, 2009; Mariotto et al., 2009), there is a tendency towards maintaining the diploid number in the tribe. However, a large amount of variation can be found in the karyotypic formulae promoted specially by pericentric inversions (Artoni \& Bertollo, 2001; Alves et al., 2003, 2006; Bueno et al., 2012; Oliveira et al., 2007, 2008; Mariotto et al., 2009; Souza et al., 2004, 2009; Ziemniczak et al., 2012). Furthermore, chromosomal rearrangements like fusions, inversions, deletions, duplications and heterocromatinization may contribute in the differentiation of the group and may be associated to morphological speciation processes (Artoni \& Bertollo, 2001; Milhomem et al., 2010; Mariotto et al., 2011; Ziemniczak, 2011; Bueno et al., 2012). According to Ziemniczak (2011), this great karyotypic diversity might have had an important role in the genetic and reproductive isolation of the Ancistrini species.

Baryancistrus xanthellus presented $2 \mathrm{n}=52$, which was already verified in species of the genera Peckoltia, Hemiancistrus, Hypancistrus, Scobinancistrus and Panaque (Artoni \& Bertollo, 2001; Oliveira et al., 2006; Souza et al., 2009; Cardoso et al., 2013; Silva et al., 2014). There was a single NOR located in the interstitial region of the short arm, in the third pair in $B$. aff. niveatus (Souza et al., 2004) and the fourth pair in B. xanthellus. This character cannot be considered specific for each genus, since species from the same genus may present sites in different locations. In Ancistrus and Hemiancistrus, for example, the single sites can be found in the short or long arms, and many times even multiple NORs were found (Oliveira et al., 2006, 2009). Like in B. aff. niveatus, the NOR was C-band positive differently from species of the genera Peckoltia and Scobinancistrus that have heterochromatic blocks adjacent to the NOR (Souza et al., 2004; Souza et al., 2009; Cardoso et al., 2013).

In some specimens of $B$. xanthellus, the NOR was heteromorphic in regards to size when compared the homologues, which was also observed by Souza et al. (2004) in some specimens of $B$. aff. niveatus. This heteromorphism is very frequent in Neotropical fish and has been explained as a duplication of ribosomal genes or by a process of accumulation of these genes in one of the homologues through unequal crossing-over (Foresti et al., 1981; Almeida-Toledo et al., 2000; Swarça et al., 2001). This might be due to the presence of constitutive heterochromatin between the ribosomal genes, which might have promoted unequal exchanges between the chromatids (Sola et al., 1988) or by accumulating constitutive heterochromatin in an adjacent position to the NOR (Vicari et al., 2008).

In $B$. xanthellus, large blocks of heterochromatin were observed in the short arm of pair 1 and the long arm of pair 10 , and conspicuous blocks were co-located with the $18 \mathrm{~S}$ and 5S rDNA sites (pairs 4 and 7, respectively) of all specimens
(Fig. 3a). A similar pattern of C-banding was observed in $B$. aff. niveatus where pairs 1 and 10 also presented one of the arms almost completely heterochromatic (Souza et al., 2004), which could be a pattern for the genus. However, $B$. aff. niveatus also presented large blocks on pairs 11 and 22 .

Ziemniczak et al. (2012) suggested that the absence of large and numerous blocks of heterochromatin seem to be a plesiomorphic character in Loricariidae. This characteristic may be proven by comparing the basal genera with the derived ones (Artoni \&Bertollo, 2001; Oliveira, 2006; Oliveira et al., 2008; Mariotto et al., 2009; Traldi et al., 2012). Large heterochromatic blocks are found in two or more chromosomal pairs in the genera Scobinancistrus, Hypancistrus and mainly in Peckoltia (Souza et al., 2009; Cardoso et al., 2013; Silva et al., 2014). This characteristic seems to be common to the Ancistrini and corroborates the suggestion proposed by Ziemniczak et al. (2012).

In Siluriformes, the mapping of the ribosomal genes $18 \mathrm{~S}$ and $5 \mathrm{~S}$ is still very incipient (Kavalco et al., 2004; Centofante et al., 2006; Mendes-Neto et al., 2011). In Loricariidae, chromosomes with syntenic markings of the $18 \mathrm{~S}$ and 5S rDNA were observed in species of Neoplecostominae, Hypoptopomatinae (Ziemniczak et al., 2012), Loricariinae (Kavalco et al., 2004), Hypostominae (Ancistrini and Hypostomini) (Mariotto et al., 2011; Traldi et al., 2013) and in the outgroup, Trichomycteridae family (Ziemniczak, 2011). Based on this data, Ziemniczak (2011) inferred that the synteny of these classes of rDNA is a plesiomorphic character in the family.

For the Baryancistrus, this is the first record of the mapping of the rDNA $5 \mathrm{~S}$ and $18 \mathrm{~S}$. The simultaneous hybridization of both probes (double-FISH) did not result in syntenic markings (Fig. 3b). This rDNA distribution in different chromosomal pairs constitutes an apomorphy in the Loricariidae (Ziemniczak, 2011).

In the Ancistrini so far, only two genera have data on 5S rDNA: Ancistrus (Mariotto et al., 2011; Favarato et al., 2016) and Hypancistrus (Silva et al., 2014). As it has been observed for the 18S rDNA, the 5S rDNA also presented variable forms among the different species of Ancistrini. In a study by Mariotto et al. (2011), in which the $18 \mathrm{~S}$ and 5S rDNA probes were hybridized in seven species of Ancistrus, all species presented 18S rDNA markings in a single pair. However, only one species, Ancistrus sp. 06, presented a single pair with $5 \mathrm{~S}$. This same species also presented synteny between the two ribosomal genes. The remaining species presented two or three pairs with the $5 \mathrm{~S}$ rDNA. In regards to the position in the chromosome, $5 \mathrm{~S}$ rDNA was found to be variable, occupying pericentromeric, interstitial, or terminal positions (Table 1).

The existence of multiple sites of the 5S rDNA in several species may be considered an important indication of the great karyotypic diversity present in Ancistrini and should correspond to an apomorphic condition in the group. Studies conducted so far in the group suggest that the localization of the 5S rDNA in a single chromosome 
pair is less frequent (Table 1), occurring in a few species of Ancistrus (Mariotto et al., 2011; Favarato et al., 2016) and in B. xanthellus. According to Martins \& Galetti (1999), the localization of the ribosomal genes in different chromosomes may be advantageous if compared to the syntenic disposition because it might avoid unfavorable arrangements (Dover, 1986), since the occurrence of unequal crossing-over might be frequent in chromosomes with co-located ribosomal genes.

In $B$. xanthellus, it is possible to visualize the heterochromatin association with $18 \mathrm{~S}$ and $5 \mathrm{~S}$ rDNA. This is a recurrent characteristic in the evolutionary history of Neotropical fishes (Vicari et al., 2003). In some cases, the heterochromatic blocks might be adjacent to the nucleolar regions, while in other cases the markings may be overlapping or intercalated (Pendás et al., 1993a,b; Artoni $\&$ Bertollo, 2001). The presence of heterochromatin, which holds large quantities of satellite DNA and transposable elements (Dimitri et al., 2009), might facilitate transposition events, moving ribosomal genes to other regions of the genome (Moreira-Filho et al., 1984; Vicari et al., 2008; Gross et al., 2009, 2010), promoting genetic duplication and unequal crossing-over, and still lead to size variation of the heterochromatin segments as well as in the number of rDNA cistrons (Sola et al., 1988; Vicari et al., 2003, 2008).

In general, B. xanthellus conserves the karyotipic macrostructure of the Ancistrini. The maintenance of $2 \mathrm{n}=52$ with a few heterochromatic blocks, a single NOR, and single rDNA sites are evidences that the genus occupies a basal position in the tribe. Our results can help to better understand the chromosomal evolution in this remarkable fish group, but the continuity of cytogenetic studies for the Baryancistrus is indispensable for a better comprehension of the evolutionary trends.

A karyotypic diversity might result in great morphological diversity and color pattern in the species of Ancistrini endemic to the Xingu River. This species diversity represents an invaluable richness; therefore, it is important that there are efforts to understand the origin, evolution, behavior, ecology, and the subsequent preservation of such diversity, since many species are threatened by extinction due to the changes in their original habitats caused by the construction of hydropower dams.

\section{Acknowledgements}

This study was supported by Instituto Nacional de Pesquisas da Amazônia/Genética, Conservação e Biologia Evolutiva (INPA/GCBEv), Fundação de Amparo a Pesquisas do Estado do Amazonas (PRONEX FAPEAM/ CNPq 003/2009), and Center for Studies of Adaptation to Environmental Changes in the Amazon (INCT ADAPTA, FAPEAM/CNPq 573976/2008-20). The authors are grateful to Laboratório de Genética e Morfofisiologia, Faculdade de Ciências Biológicas, UFPA, Altamira, PA, for support.

\section{References}

Almeida-Toledo, L. F., F. Foresti \& S. A. Toledo-Filho. 2000. Karyotipic evolution in Neotropical freshwater fish. Pp. 169-182. In: Olmo, E. \& C. A. Redi (Eds.). Chromosomes today. Basel; Boston; Berlin; Birkhäuser Verlag/Switzerland. (chromosomes today series, v. 13).

Alves, A. L., C. Oliveira \& F. Foresti. 2003. Karyotype variability in eight species of the subfamilies Loricariinae and Ancistrinae (Teleostei, Siluriformes, Loricariidae). Caryologia, 56: 57-63.

Alves, A. L., C. Oliveira \& F. Foresti. 2005. Comparative cytogenetic analysis of eleven species of subfamilies Neoplecostominae and Hypostominae (Siluriformes: Loricariidae). Genetica, 124: 127-136.

Alves, A. L., C. Oliveira, M. Nirchio, Á. Granado \& F. Foresti. 2006. Karyotypic relationships among the tribes of Hypostominae (Siluriformes: Loricariidae) with description of X0 sex chromosome system in a Neotropical fish species. Genetica, 128: 1-9.

Armbruster, J. W. 2004. Phylogenetic relationships of the suckermouth armoured catfishes (Loricariidae) with emphasis on the Hypostominae and the Ancistrinae. Zoological Journal of the Linnean Society, 141: 1-80.

Artoni, R. F. \& L. A. C. Bertollo. 2001. Trends in the karyotype evolution of Loricariidae fish (Siluriformes). Hereditas, 134: 201-210.

Bertollo, L. A. C., C. S. Takahashi \& O. Moreira Filho. 1978. Citotaxonomic considerations on Hoplias lacerdae (Pisces: Erythrinidae). Revista Brasileira de Genética, 1: 103-120.

Bueno, V., C. H. Zawadzki \& V. P. Margarido. 2012. Trends in chromosome evolution in the genus Hypostomus Lacépède, 1803 (Osteichthyes, Loricariidae): a new perspective about the correlation between diploid number and chromosomes types. Reviews in Fish Biology and Fisheries, 22: 241-250.

Cardoso, A. L., K. A. H. Sales, C. Y. Nagamachi, J. C. Pieczarka \& R. C. R. Noronha. 2013. Comparative cytogenetics of two species of genus Scobinancistrus (Siluriformes, Loricariidae, Ancistrini) from the Xingu River, Brazil. Comparative Cytogenetics, 7: 43-51.

Centofante, L., L. A. C. Bertollo \& O. Moreira-Filho. 2006. Cytogenetic characterization and description of an XX/ $\mathrm{XY}_{1} \mathrm{Y}_{2}$ sex chromosome system in catfish Harttia carvalhoi (Siluriformes, Loricariidae). Cytogenetic and Genome Research, 112: 320-324.

Dimitri, P., R. Caizzi, E. Giordano, M. C. Accardo, G. Lattanzi \& G. Biamonti. 2009. Constitutive heterochromatin: a surprising variety of expressed sequences. Chromosoma, 118: 419-435.

Dover, G. A. 1986. Molecular drive in multigene families: how biological novelties arise, spread and are assimilated. Trends in Genetics, 2: 159-165.

Eschmeyer, W. N. \& J. D. Fong. 2015. Species of Fishes by family/subfamily in the Catalog of fishes. San Francisco, CA, California Academy of Sciences. Electronic version. Available from: http://research.calacademy.org/research/ ichthyology/catalog/SpeciesByFamily.asp. (July 2015). 
Favarato, R. M., M. Silva, R. R. Oliveira, R. F. Artoni, E. Feldberg \& D. A. Matoso. 2016. Cytogenetic diversity and the evolutionary dynamics of rDNA genes and telomeric sequences in the Ancistrus genus (Loricariidae: Ancistrini). Zebrafish, 13: 103-111.

Ferraris, C. J., Jr. 2007. Checklist of catfishes, recent and fossil (Osteichthyes: Siluriformes), and catalogue of Siluriform primary types. Zootaxa, 1418: 1-628.

Fisch-Muller, S. 2003. Subfamily Ancistrinae (Armored catfishes). Pp. 373-400. In: Reis, R. E., S. O. Kullander \& C. J. Ferraris, Jr. (Orgs.). Check list of the freshwater fishes of South and Central America. Porto Alegre, Edipucrs.

Foresti, F., L. F. Almeida-Toledo \& S. A. Toledo. 1981. Polymorphic nature of nucleolus organizer regions in fishes. Cytogenetics and Cell Genetics, 31: 137-144.

Gross, M. C., C. H. Schneider, G. T. Valente, C. Martins \& E. Feldberg. 2010. Variability of $18 \mathrm{~S}$ rDNA locus among Symphysodon fishes: chromosomal rearrangements. Journal of Fish Biology, 76: 1117-1127.

Gross, M. C., C. H. Schneider, G. T. Valente, J. I. R. Porto, C. Martins \& E. Feldberg. 2009. Comparative cytogenetic analysis of the genus Symphysodon (Discus Fishes, Cichlidae): chromosomal characteristics of retrotransposons and minor ribosomal DNA. Cytogenetic and Genome Research, 127: 43-53.

Howell, W. M. \& D. A. Black. 1980. Controlled silver-staining of nucleolus organizer regions whit a protective colloidal developer: a 1-step method. Experientia, 36: 1014-1015.

Isbrücker, I. J. H. 1980. Classification and catalogue of the mailed Loricariidae (Pisces, Siluriformes). Verslagen en Technische Gegevens, Instituut voor Taxonomische Zoologie (Zoologisch Museum), Universiteit van Amsterdam, 22: 1-181.

Junk, W. J. \& J. A. S. N. Mello. 1990. Impactos ecológicos das represas hidrelétricas na bacia amazônica brasileira. Estudos Avançados, 4: 126-143.

Kavalco, K. F., R. Pazza, L. A. C. Bertollo \& O. Moreira-Filho. 2004. Heterochromatin characterization of four fish species of the family Loricariidae (Siluriformes). Hereditas, 141: 237-242.

Kavalco, K. F., R. Pazza, L. A. C. Bertollo \& O. Moreira-Filho. 2005. Karyotypic diversity and evolution of Loricariidae (Pisces: Siluriformes). Heredity, 94: 180-186.

Lara, M. C. S. 1998. Aspectos citogenéticos de quatro espécies de peixes da subfamília Ancistrinae (Siluriformes: Loricariidae) da bacia do rio Paraná. Unpublished Msc. Dissertation, Universidade Estadual de Maringá, Maringá, 46f.

Levan, A., K. Fredga \& A. A. Sandberg. 1964. Nomenclature for centromeric position on chromosomes. Hereditas, 52: 201- 220.

Lujan, N. K., J. W. Armbruster, N. R. Lovejoy \& H. LópezFernández. 2015. Multilocus molecular phylogeny of the suckermouth armored catfishes (Siluriformes: Loricariidae) with a focus on subfamily Hypostominae. Molecular Phylogenetics and Evolution, 82: 269-288.

Mariotto, S. 2009. Estudo citogenético clássico e molecular em quinze espécies da tribo Ancistrini (Siluriformes, Loricariidae) de três bacias hidrográficas brasileiras. Unpublished Ph. D. Dissertation, Universidade Federal de São Carlos, São Carlos, SP, 101p.
Mariotto, S., L. Centofante, R. F. Artoni, M. R. Vicari \& O. Moreira Filho. 2011. Chromosomal diversification in ribosomal DNA sites in Ancistrus Kner, 1854 (Loricariidae, Ancistrini) from three hydrographic basins of Mato Grosso, Brazil. Comparative Cytogenetics, 5: 289-300.

Mariotto, S., L. Centofante, C. S. Miyazawa, L. A. C. Bertollo \& O. Moreira Filho. 2009. Chromosome polymorphism in Ancistrus cuiabae Knaack, 1999 (Siluriformes: Loricariidae: Ancistrini). Neotropical Ichthyology, 7: 595-600.

Mariotto, S., L. Centofante \& O. Moreira Filho. 2013. Diversity and chromosomal evolution in the genus Ancistrus Kner, 1854 (Loricariidae: Ancistrini) from three hydrographic basins of Mato Grosso State, Brazil. Neotropical Ichthyology, 11: $125-131$.

Mariotto, S. \& C. S. Miyazawa. 2006. Ancistrus cf. dubius (Siluriformes, Ancistrinae), a complex of species. 1. Chromosomic characterization of four populations and occurrence of sexual chromosomes of type $\mathrm{XX} / \mathrm{XY}$, in the Pantanal Basin of Mato Grosso, Brazil. Caryologia, 59: 299-304.

Martins, C. \& P. M. Galetti, Jr. 1999. Chromosomal localization of 5S rDNA genes in Leporinus fish (Anostomidae, Characiformes). Chromosome Research, 7: 363-367.

Mendes-Neto, E. O., M. R. Vicari, R. F. Artoni \& O. MoreiraFilho. 2011. Description of karyotype in Hypostomus regani (Ihering, 1905) (Teleostei, Loricariidae) from the Piumhi River in Brazil with comments on karyotype variation found in Hypostomus. Comparative Cytogenetics, 5: 133-142.

Milhomem, S. S. R., R. R. Castro, C. Y. Nagamachi, A. C. P. Souza, E. Feldberg \& J. C. Pieczarka. 2010. Different cytotypes in fishes of the genus Hypostomus Lacépède, 1803, (Siluriformes: Loricariidae) from Xingu River (Amazon region, Brazil). Comparative Cytogenetics, 4: 45-54.

Moreira-Filho, O., L. A. C. Bertollo \& P. M. Galetti, Jr. 1984. Structure and variability of nucleolar organizer regions in Parodontidae fish. Canadian Journal of Genetics and Cytology, 26: 564-568.

Oliveira, C., L. F. Almeida-Toledo, F. Foresti \& S. A. Toledo. 1988. Supernumerary chromosomes, robertsonian rearrangement and multiple NORs in Corydoras- aeneus (Pisces, Siluriformes, Callichthyidae). Caryologia, 41: 227-236.

Oliveira, R. R. 2006. Diversidade cariotípica entre dez espécies do gênero Ancistrus (Siluriformes, Loricariidae) da Bacia Amazônica: estrutura e mecanismos de evolução cromossômica. Unpublished master's thesis. Instituto Nacional de Pesquisas da Amazônia, Manaus, 96p.

Oliveira, R. R., E. Feldberg, M. B. Anjos \& J. Zuanon. 2007. Karyotype characterization and ZZ/ZW sex chromosome heteromorphism in two species of the catfish genus Ancistrus Kner, 1854 (Siluriformes: Loricariidae) from the Amazon basin. Neotropical Ichthyology, 5: 301-306.

Oliveira, R. R., E. Feldberg, M. B. Anjos \& J. Zuanon. 2008. Occurrence of multiple sexual chromosomes (XX/ $\mathrm{XY}_{1} \mathrm{Y}_{2}$ and $\left.\mathrm{Z}_{1} \mathrm{Z}_{1} \mathrm{Z}_{2} \mathrm{Z}_{2} / \mathrm{Z}_{1} \mathrm{Z}_{2} \mathrm{~W}_{1} \mathrm{~W}_{2}\right)$ in catfishes of the genus Ancistrus (Siluriformes: Loricariidae) from the Amazon Basin. Genetica, 134: 243-249. 
Oliveira, R. R., E. Feldberg, M. B. Anjos \& J. Zuanon. 2009. Mechanisms of chromosomal evolution and its possible relation to natural history characteristics in Ancistrus catfishes (Siluriformes: Loricariidae). Journal of Fish Biology, 75: 22092225.

Oliveira, R. R., I. L. Souza \& P. C. Venere. 2006. Karyotype description of three species of Loricariidae (Siluriformes) and occurrence of the ZZ/ZW sexual system in Hemiancistrus spilomma Cardoso \& Lucinda, 2003. Neotropical Ichthyology, 4: 93-97.

Pendás, A. M., P. Morán \& E. García-Vásquez. 1993a. Ribosomal RNA genes are interspersed throughout a heterochromatic chromosome arm in Atlantic salmon. Cytogenetics and Cell Genetics, 63: 128-130.

Pendás, A. M., P. Morán \& E. García-Vásquez. 1993b. Multichromosomal location of ribosomal RNA genes and heterochromatin association in brown trout. Chromosome Research, 1: 63-67.

Pinkel, D., T. Straume \& J. W. Gray. 1986. Cytogenetic analysis using quantitative, high-sensitivity, fluorescence hybridization. Proceedings of the National Academy of Sciences, 83: 2934-2938.

Rapp Py-Daniel, L., J. Zuanon \& R. R. de Oliveira. 2011. Two new ornamental loricariid catfishes of Baryancistrus from rio Xingu drainage (Siluriformes: Hypostominae). Neotropical Ichthyology, 9: 241-252.

Reis, R. E., E. H. L. Pereira \& J. W. Armbruster. 2006. Delturinae, a new loricariid catfish subfamily (Teleostei, Siluriformes), with revisions of Delturus and Hemipsilichthys. Zoological Journal of the Linnean Society, 147: 277-299.

Reis, R. E., S. O. Kullander \& C. J. Ferraris, Jr. (Orgs.). 2003. Check list of the freshwater fishes of South and Central America. Porto Alegre, Edipucrs, 729p.

Sambrook, J., E. F. Fritsch \& T. Maniatis. 1989. Molecular cloning: a laboratory manual. 2nd ed. Cold Spring Harbor, N.Y., Cold Spring Harbor Laboratory Press, 3v.

Schaefer, S. A. 1986. Historical biology of the loricariid catfishes: phylogenetics and functional morphology. Unpublished Ph.D. Dissertation, The University of Chicago, Chicago, 290p.

Schaefer, S. A. 1987. Osteology of Hypostomus plecostomus (Linnaeus), with a phylogenetic analysis of the loricariid subfamilies (Pisces: Siluroidei). Contributions in Science, Natural History Museum of Los Angeles County, 394: 1-31.

Silva, M., E. D. Ribeiro, D. A. Matoso, L. M. Sousa, T. Hrbek, L. Rapp Py-Daniel \& E. Feldberg. 2014. Chromosomal polymorphism in two species of Hypancistrus (Siluriformes: Loricariidae): an integrative approach for understanding their biodiversity. Genetica, 142: 127-139.

Sola, L., G. L. Natili \& S. Cataudella. 1988. Cytogenetical characterization of Odontesthes bonariensis (Pisces, Atherinidae), an Argentine species introduced in Italy. Genetica, 77: 217-224.

Souza, A. C. P. 2003. Descrição cariotípica de peixes dos gêneros Baryancistrus, Parancistrus, Peckoltia e Ancistrus (Ancistrinae, Loricariidae) da Bacia Amazônica. Unpublished master's thesis, Universidade Federal do Pará/Museu Paraense Emílio Goeldi, Belém, Pará, 130f., il.
Souza, A. C. P., C. Y. Nagamachi, S. S. R. Milhomem, E. Feldberg \& J. C. Pieczarka. 2009. Cytogenetic analysis in catfish species of the genus Peckoltia Miranda Ribeiro, 1912 (Teleostei: Siluriformes: Loricariidae). Comparative Cytogenetics, 3: 103-109.

Souza, A. C. P., A. L. Nascimento, J. R. Carvalho Jr., R. M. S. Barros, E. Feldberg, C. Y. Nagamachi \& J. C. Pieczarka. 2004. Karyotypic analysis of Baryancistrus aff. niveatus (Ancistrinae, Loricariidae) by C-banding, Ag-NOR, CMA, DAPI and FISH. Caryologia, 57: 219-223.

Sumner, A. T. 1972. A simple technique for demonstrating centromeric heterochromatin. Experimental Cell Research, 75: 304-306.

Swarça, A. C., M. M. Cestari, L. Giuliano-Caetano \& A. L. Dias. 2001. Cytogenetic characterization of the large South American siluriform fish species Zungaro zungaro (Pisces, Pimelodidae). Chromosome Science, 5: 51-55

Tchaicka, L. \& V. P. Margarido. 1999. Descrição do cariótipo de Ancistrus sp. (Pisces, Loricariidae, Ancistrinae) coletado no rio Alto Alegre, bacia do rio Iguaçú. Congresso Nacional de Genética, 45.

Traldi, J. B., D. R. Blanco, M. R. Vicari, J. F. Martinez, R. L. Lui, A. V. Barros, R. F. Artoni \& O. Moreira-Filho. 2013. Chromosomal diversity in Hypostomus (Siluriformes, Loricariidae) with emphasis on physical mapping of $18 \mathrm{~S}$ and $5 \mathrm{~S}$ rDNA sites. Genetics and Molecular Research, 12: 463-471.

Traldi, J. B., M. R. Vicari, D. R. Blanco, J. F. Martinez, R. F. Artoni \& O. Moreira-Filho. 2012. First karyotype description of Hypostomus iheringii (Regan, 1908): a case of heterochromatic polymorphism. Comparative Cytogenetics, 6: 115-125.

Vicari, M. R., R. F. Artoni \& L. A. C. Bertollo. 2003. Heterochromatin polymorphism associated with 18S rDNA: a differential pathway among Hoplias malabaricus fish populations. Cytogenetic and Genome Research, 101: 24-28.

Vicari, M. R., R. F. Artoni, O. Moreira-Filho \& L. A. C. Bertollo. 2008. Colocalization of repetitive DNAs and silencing of major rRNA genes. A case report of the fish Astyanax janeiroensis. Cytogenetic and Genome Research, 122: 67-72.

Ziemniczak, K. 2011. Estudo citogenético em espécies de Loricariidae (Pisces, Siluriformes) das nascentes dos rios Ribeira e Tibagi, Ponta Prossa - PR. Unpublished master's dissertation, Universidade Federal do Paraná, Curitiba, PR, $82 \mathrm{f}$.

Ziemniczak, K., A. V. Barros, K. O. Rosa, V. Nogaroto, M. C. Almeida, M. M. Cestari, O. Moreira-Filho, R. F. Artoni \& M. R. Vicari. 2012. Comparative cytogenetics of Loricariidae (Actinopterygii: Siluriformes): emphasis in Neoplecostominae and Hypoptopomatinae. Italian Journal of Zoology, 79: 492-501.

Zuanon, J. A. S. 1999. História natural da ictiofauna de corredeiras do rio Xingu, na região de Altamira, Pará. Unpublished Ph.D. Thesis, Universidade Estadual de Campinas, Campinas, $199 \mathrm{f}$.

Submitted July 24, 2015 Accepted February 09, 2016 by Cláudio Oliveira 